\title{
Peningkatan Prestasi Belajar Ilmu Pengetahuan Alam melalui Model Pembelajaran Inside Outside Cyrcle (IOC)
}

\author{
Sukari \\ SDN 2 Dukuh Kecamatan Watulimo Kabupaten Trenggalek \\ Email:sdn22dukuh@gmail.com
}

\section{Tersedia Online di \\ http://www.jurnal.unublitar.ac.id/ index.php/briliant

\begin{tabular}{l}
\hline Sejarah Artikel \\
\hline Diterima pada 2 April 2017 \\
Disetuji pada 6 April 2017 \\
Dipublikasikan pada 1 Mei 2017 \\
Hal. 197-201
\end{tabular}

Kata Kunci:

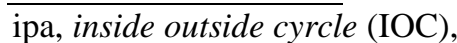

\begin{abstract}
Abstrak: Melihat tingkat ketuntasan belajar yang masih cukup rendah guru mencoba mengembalikan konsep pemikiran pada konsep pembelajaran IPA, dimana siswa dan lingkungan adalah merupakan suatu kesatuan yang tidak terpisahkan. Oleh karena itu pembelajaran dilakukan dengan mengkaitkan antara pengalaman dan pengetahuan siswa dengan materi yang dikaji. Sesuai dengan hal tersebut, peneliti mengambil langkah untuk meneliti tentang penerapan model pembelajaran Inside Outside Cyrcle (IOC). Hasil menunjukkan Terjadi peningkatan prestasi belajar mata pelajaran Ilmu Pengetahuan Alam melalui model pembelajaran Inside Outside Cyrcle.
\end{abstract}

Pembelajaran IPA merupakan pembelajaran yang mengungkap tentang lingkungan dengan berbagai habitat yang ada di dalamnya. Siswa sebagai anggota di lingkungan, juga mempunyai pengamalan yang diperoleh dari interalsi dengan lingkungan itu sediri. Oleh karena itu pembelajaran IPA hendaknya dilakukan dengan mengkaitkan antara pengalaman siswa dengan konsep yang dipelajari. Tetapi seringkali guru lupa dengan hakekat dari pembelajaran IPA itu sendiri. Karena dikejar dengan target yang harus selesai pada waktunya, guru harus menerapkan metode pembelajaran yang dapat dilakukan dengan waktu yang relativ singkat.

Pembelajaran pra siklus guru menerapkan metode ceramah yang divariasikan dengan tanya jawab. Guru sudah berupaya untuk menggali pengetahuan siswa lewat Tanya Jawab yang dilakukan. Akan tetapi pembelajaran masih belum terlihat maksimal, karena siswa yang mau bertanya hanya siswa tertentu saja.

Materi pada tahap pra siklus adalah "Cara TumbuhanHijau Membuat Makanan". KKM yang dipasang oleh guru pada materi tersebut setinggi 70 . Jumlah siswa ada 22. Sedangkan jumlah siswa tuntas sebesar 14 siswa $(63,64 \%)$. Siswa aktif sebanyak 11 siswa (50\%). Guru menerapkan metode ceramah bervariasi.

Melihat tingkat ketuntasan belajar yang masih cukup rendah guru mencoba mengembalikan konsep pemikiran pada konsep pembelajaran IPA, dimana siswa dan lingkungan adalah merupakan suatu kesatuan yang tidak terpisahkan. Oleh karena itu pembelajaran dilakukan dengan mengkaitkan antara pengalaman dan pengetahuan siswa dengan materi yang dikaji.

Refleksi yang dapat dilaksanakan dari pelaksanaan tahap pra siklus adalah sebagai berikut, (1) Guru perlu menerapkan metode pembelajaran yang kurang menarik, (2) Siswa kurang aktif dalam pembelajaran, (3) Perlu media yang menarik bagi siswa, bukan hanya buku teks. 
Sesuai dengan hal tersebut, guru mengambil langkah untuk menerapkan model pembelajaran Inside Outside Cyrcle (IOC). Adapun tujuan yang ingin dicapai dalam penelitian ini adalah: "Untuk mengetahui peningkatan prestasi belajar mata pelajaran Ilmu Pengetahuan Alam melalui model pembelajaran Inside Outside Cyrcle (IOC) bagi siswa kelas V semester I tahun pelajaran 2015/2016 di SDN 2 Dukuh Kecamatan Watulimo Kabupaten Trenggalek"

\section{METODE}

\section{Rancangan Penelitian}

Untuk memahami apa yang dimaksud dengan PTK, dapat dilihat dari kutipan berikut: Penelitian Tindakan kelas adalah : "Bentuk penelitian reflektif yang dilakukan oleh guru sendiri yang hasilnya dapat dimanfaatkan sebagai alat untuk pengembangan kurikulum, pengembangan sekolah, pengembangan keahlian mengajar, dan sebagainya" (Sukidin, 2012:14).

Pada penelitian ini, peneliti merencanakan penelitian dilakukan selama 3 bulan. Yakni pada bulan Oktvober, November, dan Desember tahun 2015, cdengan perencanaan waktu sebagai berikut, (1) Pada Minggu I bulan Oktober 2015 dilaksanakan tahap pra siklus, (2) Pada Min ggu II bulan Oktober 2015 dilaksanakan tahap siklus I, (3) Pada Minggu III bulan Oktober 2015 dilaksanakan tahap II.

\section{Tahap Perencanaan}

Pada tahap perencanaan dilaksanakan kegiatan sebagai berikut, (1) Mengidentifikasi masalah yang muncul. Untuk siklus I dan II didasarkan pada hasiul refleksi, (2) Merencanakan pembelajaran yang disusun dalam RPP, (3) Menyusun LKS, (4) Menyiapkan sumber belajar, (5) Menentukan media pembelajaran, (6) Menyusun soal evaluasi, (7) Menyusun format pengamatan keaktifan.

\section{Tahap Pelaksanaan Tindakan}

Tahap tindakan yang dilakukan guru sesuai dengan model pembelajaran Inside Outside Cyrcle adalah, (1) Langkah pertama, separuh kelas berdiri membentuk lingkaran kecil dan menghadap keluar, (2) Langkah kedua, separuh kelas lainnya membentuk lingkaran di luar lingkaran pertama dan menghadap ke dalam, (3) Langkah ketiga, kemudian dua siswa yang berpasangan dari lingkaran kecil dan besar berbagi informasi. Pertukaran informasi ini bisa dilakukan oleh semua pasangan dalam waktu yang bersamaan, (4) Langkah keempat, siswa yang berada di lingkaran kecil diam di tempat, sementara siswa yang berada di lingkaran besar bergeser satu atau dua langkah searah jarum jam, sehingga masing-masing siswa mendapatkan pasangan baru, (5) Langkah terakhir, giliran siswa yang berada di lingkaran besar yang membagi informasi. Demikian seterusnya.

\section{Tahap Pengamatan}

Walaupun penelitian ini meneliti tentang peningkatan prestasi belajar siswa, tetapi guru tetap mengadakan pengamatan. Pengamatan yang dilakukan adalah mengamati keaktifan siswa selama kegiatan inti pembelajaran berlangsung. 


\section{Tahap Refleksi}

Agar dapat melaksanakan pembelajaran yang lebih baik pada siklus berikutnya, guru mengadakan refleksi. Kekurangan yang ada pada pembelajaran siklus sebelumnya digunakan sebagai bahan untuk mengadakan refleksi. Dengan demikian maka peneliti dapat mengadakan perbaikan pada tahap/siklus berikutnya. Secara rinci, aktifitas pada tahap refleksi adalah sebagai berikut, (1) Menganalisis hasil tes akhir, (2) Menganalisis hasil pengamatan keaktifan siswa, (3) Memperbaiki pembelajaran siklus berikutnya.

\section{Subjek Penelitian}

Subjek yang diteliti pada penelitian ini adalah seluruh siswa kelas V semester I tahun pelajaran 2015/2016 di SDN 2 Dukuh Kecamatan Watulimo Kabupaten Trenggalek, yang berjumlah 22 siswa, dan terdiri 9 siswa laki-laki dan 13 siswa perempuan.

Peneliti memilih subjek penelitan ini karena peneliti sudah sangat akrab dengan subjek peneliitian tersebut. Peneliti bekerja sebagai guru di lembaga tersebut dan mengajar di kelas yang sama. Oleh karena itu subjek penelitian tidak akan merasa asing dengan peneliti, sehingga pembelajaran dapat berlamgsung demngan wajar.

\section{Instrumen Penelitian}

Penelitian ini menggunakan 2 macam instrument penelitian, yaitu lembar pengamatan dan lembar soal tes akhir.

\section{Teknik Pengumpulan Data}

Penelitian pasti memerlukan data. Data harus dikumpulkan dengan menggunakan teknik pengumpulan data yang relevan. Kesalahan dalam mengambil data akan menghasilkan kesimpulan yang salah pula. Penelitian ini memerlukan data mengenai data prestasi belajar siswa sebagai data utama dan data tentang keaktifan siswa sebagai data pendukung.

\section{Teknik Analisis Data}

Analisis data dilakukan dengan teknik analisis data statistiik. Teknik ini mengolah data yang berwujud angka. Untuk analisis data dilakukan menghitung jumlah siswa aktif dan siswa pasif. Untuk menghitung prosentase siswa aktoif dan pasif dilakukan sebagai berikut:

$$
\begin{array}{lll}
\text { Siswa aktif }= & \frac{\text { SiswaAktif }}{\text { JumlahSiswaSeluruhnya }} \times 100 \% \\
\text { Siswa tidak aktif }= & \frac{\text { SiswaTidakAktif }}{\text { JumlahSiswaSeluruhnya }} \times 100 \%
\end{array}
$$

Menganalisis hasil tes akhir siswa, dengan rumus:

$$
\mathrm{NA}=\frac{\text { SkorPerolehan }}{\text { SkorMaksimal }} \times 100
$$




\section{HASIL}

\section{Pra Siklus}

Tahap pra siklus membahas materi : "Adaptasi hewan dengan lingkungannya." Guru menentukan KKM yang ditentukan pada materi ini adalah 70. Tahap pelaksanaan pra siklus dilakuan dengan melakukan kegiatan-kegiatan sebagai berikut, (1) Merencanakan pembelajaran yang disusun dalam RPP, (2) Menyusun LKS, (3) Menyiapkan sumber belajar, (4) Menentukan media pembelajaran, (5) Menyusun soal evaluasi, (6) Menyusun format pengamatan keaktifan. Tindakan pada tahap pra siklus dilakukan dengan melaksanakan pemvbelajaran yang menerapkan metode ceramah dan tanya jawab. Setelah melaksanakan proses pembelajaran, dilakukan tes akhir.

\section{Siklus I}

Guru merencanakan pembelajaran siklus I dengan beberapa kegiatan seperti pada pra siklus. Pelaksanaan siklus I dilaksanakan sesuai dengan model pembelajaran yang telah ditentukan, yalni Inside Outside Cyrcle. Adapun ;lamgkah-langkahnya adalah sebagain berikiut, (1) Langkah pertama, separuh kelas berdiri membentuk lingkaran kecil dan menghadap keluar, (2) Langkah kedua, separuh kelas lainnya membentuk lingkaran di luar lingkaran pertama dan menghadap ke dalam, (3) Langkah ketiga, kemudian dua siswa yang berpasangan dari lingkaran kecil dan besar berbagi informasi. Pertukaran informasi ini bisa dilakukan oleh semua pasangan dalam waktu yang bersamaan, (4) Langkah keempat, siswa yang berada di lingkaran kecil diam di tempat, sementara siswa yang berada di lingkaran besar bergeser satu atau dua langkah searah jarum jam, sehingga masing-masing siswa mendapatkan pasangan baru, (5) Langkah terakhir, giliran siswa yang berada di lingkaran besar yang membagi informasi. Demikian seterusnya.

Tahap siklus I dilaksanakan pengamatan tentang keaktifan siswa. Guru melaksanakan pengamatan pada saat kegiatan inti berlangsung. Siswa aktif pada siklus I adalah 17 siswa $(77,27 \%)$ dan siswa yang tidak aktif sebanyak 5 siswa $(22,73)$. Pada tahap siklus I, refleksi yang dapat disampaikan adalah sebagai berikut:, (1) Beberapa pasangan kurang dapat berkomunikasi dengan baik karena siswa berpasangan sesuai dengan kehendaknya sendiri-sendiri. Pada siklus II pasangan ditentukan ooleh guru, sehingga komunikasi antar siswa berjalan seimbang antara pasangan yang satu dengan yang lain, (2) Selain membaca buku teks, sebaiknya guru menyampaikan materi awal, sehingga dapat lebih menanamkan pengertian kepada siswa mengenai materi yang akan dibahas.

\section{Siklus II}

Guru merencanakan pembelahjaran siklus I dengan beberapa kegiatanseperti siklus I. Pelaksanaan siklus II dilaksanakan sesuai dengan model pembelajaran yang telah ditentukan, yakni Inside Outside Cyrcle. Tahap siklus II dilaksanakan pengamatan tentang keaktifan siswa. Guru melaksanakan pengamatan pada saat kegiatan inti berlangsung. Siswa aktif pada siklus II adalah 20 siswa $(90,91 \%)$ dan siswa yang tidak aktif sebanyak 2 siswa $(9,09)$.

200 BRILIANT: Jurnal Riset dan Konseptual Volume 2 Nomor 2, Mei 2017 


\section{PEMBAHASAN}

Berdasarkan pengamatan siklus I, peneliti dapat menyampaikan hal-hal adalah, (1) Siswa yang mencapai kategori sangat baik sebanyak 3 siswa (13,64\%), (2) Siswa yang mencapai kategori baik sebanyak 3 siswa $(13,64 \%)$, (3) Siswa yang mencapai kategori lebih dari cukup sebanyak 4 siswa $(18,18 \%)$, (4) Siswa yang mencapai kategori cukup sebanyak 7 siswa $(31,82)$, (5) Siswa yang mencapai kategori kurang sebanyak 5 siswa $(22,73 \%)$. Berdasarkan data tersebut, maka sebanyak $17(77,27 \%)$ siswa sudah tuntas dalam belajar dan sebanyak 5 $(22,73 \%)$ siswa bellum tuntas dalam belajar. Dan akhirnya pada siklus dua telah tercapai ketuntasan yang diatas kriteria. Penerapan dari model Inside Outside Cyrcle dinyatakan berhasil.

\section{KESIMPULAN}

Terjadi peningkatan prestasi belajar mata pelajaran Ilmu Pengetahuan Alam melalui model pembelajaran Inside Outside Cyrcle (IOC) bagi siswa kelas V semester I tahun pelajaran 2015/2016 di SDN 2 Dukuh Kecamatan Watulimo Kabupaten Trenggalek.

\section{SARAN}

Berdasarkan keseluruhan proses dan hasil penelitian, maka perlu disampaikan saran sebagai berikut: (1) Diharapkan agar guru dapat menambah semangat diri untuk selalu melaksanakan pembelajaran yang menyenangkan, sehingga mutu lulusan dapat lebih baik. (2) Diharapkan agar siswa dapat meningkatkan motivasi beljar, sehingga prestasi dapat maksimal. Siswa juga diharapkan agar tidak terlalu menggantungkan diri pada orang lain untuk melaksanakan kegiatan belajar, misalnya menggantungkan diri pada guru, pada orang tua, atau pada yang lain, karena motivasi yang berasal dari dalam diri sendiri lebih penting.

\section{DAFTAR RUJUKAN}

Aqib, Zainal. 2012. Profesionalisme Guru dalam Pembelajaran. Surabaya: Insan Cendekia.

Arikunto, Suharsimi. 2009. Prosedur Penelitian Suatu Pendekatan Praktek. Jakarta: Rineka Cipta

Fathurrohman, Pupuh. 2010. Strategi Belajar Mengajar. Bandung: Refika Aditama.

Lie, Anita. 2008. Cooperative Learning: Mempraktikkan Cooperative Learning Di Ruang-ruang Kelas. Jakarta: Grasindo.

Prayitno, 2013. Dasar-Dasar Bimbingan dan Konseling. Jakarta: Rineka Cipta.

Sukidin. 2012. Manajemen Penelitian Tindakan Kelas. Surabaya: Insan Cendekia. Surya, HM. 2003. Kapita Selekta Kependidikan SD. Jakarta: Universitas Terbuka. Sudarwan, Danim. 2011. Psikologi Pendidikan. Bandung:Alfabeta

Yusuf, Syamsu. 2010. Landasan Bimbingan dan Konseling. Bandung Remadja Rosdakarya. 